Journal of

Strategic Management

(JSM)

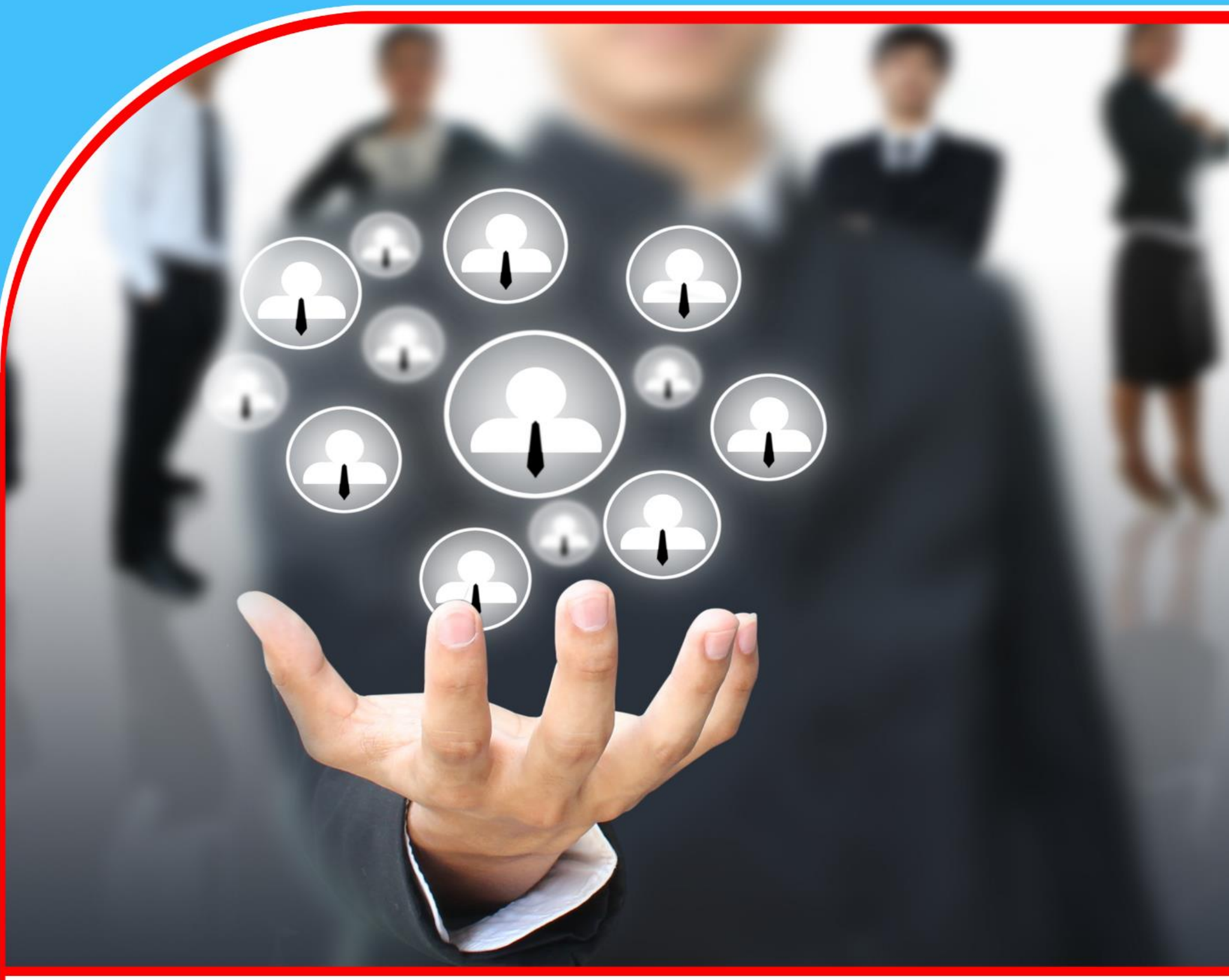

PROCEDURAL JUSTICE AND ORGANIZATIONAL CITIZENSHIP BEHAVIOUR OF DEPOSIT MONEY

BANKS IN RIVERS STATE, NIGERIA

Vito Baridula Dr. John Mark

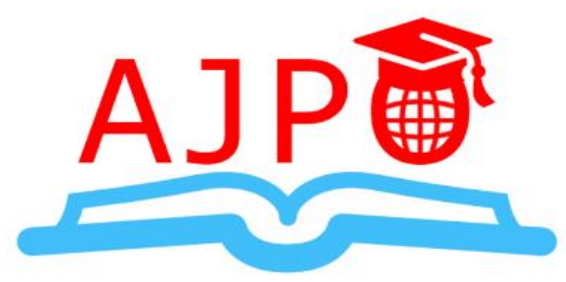




\title{
PROCEDURAL JUSTICE AND ORGANIZATIONAL CITIZENSHIP BEHAVIOUR OF DEPOSIT MONEY BANKS IN RIVERS STATE, NIGERIA
}

\author{
Vito Baridula \\ Doctoral Candidate, Department of Management, Faculty of Management Sciences, Rivers, State \\ University,Nkpolu-Oroworukwo, PMB 5080, Port Harcourt, Nigeria. \\ Corresponding author's E-mail: baridulavito@yahoo.com \\ Dr. John Mark \\ Department of Management, Faculty of Management Sciences, Rivers, State University,Nkpolu- \\ Oroworukwo, PMB 5080, Port Harcourt, Nigeria
}

\begin{abstract}
Purpose: This study investigated the relationship between procedural justice and organizational citizenship behaviour in Deposit Money Banks in Rivers State. The effects of procedural justice was tested on organizational citizenship behaviour measures such as altruism and sportsmanship.

Methodology: The study adopted a cross sectional survey design and data was generated from 193 respondents from the target Deposit Money Banks in Rivers State. As a quantitative study, the primary data collection instrument for the study was the structured questionnaire. The test for the reliability for the instrument was carried out using the Cronbach alpha reliability instrument with a reliability threshold of 0.70 . The Analysis comprised of the univariate (single variable assessments) bivariate (test for hypothetical relationships) while the bivariate analysis was carried out using the Spearman's rank order correlation coefficient at a 0.05 level of significance.

Findings: Findings from the study revealed that workplace justice significantly impacts on the measures of OCB (altruism and sportsmanship) and also organizational culture was revealed to also significantly moderate the relationship between workplace justice and organizational citizenship behaviour in Deposit Money Banks in Rivers State. Based on the findings, it was concluded that there is significant relationship between the predictor and the measures of the criterion variables.

Contribution to practice and Policy: The study recommended that OCB within an organization could be significantly increased by enhancing organizational fairness, particularly procedural justice. Bank managers should first improve the procedural justice and hence increase overall levels of perceived justice by involving employees in the procedures used in making decisions and allocating rewards.
\end{abstract}

Keywords: Procedural Justice, Organizational citizenship behavior, altruism, sportsmanship 
European Journal of Physical Sciences

ISSN 2520-4638 (Online)

Vol.4, Issue 1, pp 40 - 55, 2019

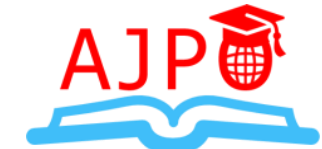

www.ajpojournals.org

\section{INTRODUCTION}

Organizational citizenship behaviour (OCB) is argued to be one of the vital factors that affects the effectiveness of an organization (Podsakoff, Whitting, Podsakoff, \& Blume, 2009). OCB has been quite a concerned problem in organizational behaviour field and it has been commonly used as a criterion variable (Azmi, Desai, \&Jayakrishnan, 2016). A major goal or purpose management is to enhance the effectiveness and overall performance of organizations ( Ng,Ke, \& Raymond, 2014). Amongst some of the identified factors, OCB has been recognized as one of the substantial contributors to the productivity and effectiveness of organizations (Podsakoff et al., 2009).

One way for organizations to be more effective and efficient is to have "good people". That is, employees who work hard, are honest and who will do their utmost to contribute to the effectiveness and efficiency of the organization, but motivating employees is not very easy. Many theories have addressed this subject. Organizational citizenship behaviour (OCB) probably has existed from the very beginning of the creation of organizations in their simplest form, but OCB has been acknowledged by researchers as a separate phenomenon only since 1983 (Organ, 1988).

Katz (1964) described OCB as a class of discretionary and spontaneous behaviours that are beyond explicit role requirements, but that are essential for organizational effectiveness. Smith et al., (1983), in a report of empirical research on the nature and antecedents of such extra-role contributions, conceptualize these contributions as organizational citizenship behaviour (OCB), later defined by Organ as individual behaviour that is discretionary, not directly or explicitly recognized by the formal reward system, and that in the aggregate promotes the effective functioning of the organization (Farh, Zhong \& Organ, 2004).Furthermore, the environment of workplace will become more compassionate, healthy, and supportive which will develop organizations' success when employees exhibit OCB (Day \& Carroll, 2004). Employees who behave voluntarily without being recognized by the formal reward system are known as employees that exhibit OCB, this attribute enhances the performance of organizations (Podsakoff, Podsakoff, Mackenzie, Maynes, Trevor, \&Spoelma, 2014).

Borman and Motowidlo (2014) noted that the incidence of conflict and strive within the organization could most times be as a result of the lack of the spirit of sportsmanship, courtesy or civic virtue. In their opinion, the absence of OCB within a work environment creates room for negativity, spite, disrespect and unhealthy rivalry. In their assessment they link some of these problems to workers perceptions of the workplace as either being unfair or favouring a select set of individuals who they turn into targets of gossip, and disrespect; indicating injustice within the workplace. The unwillingness to treat workers fairly and on the same basis is as they noted, a major impediment to OCB. By this, Borman and Motowidlo (2014) identify procedural justice as a possible predictor of $\mathrm{OCB}$.

Employees are not only interested in fair outcomes but also interested in fair process for the determination of their outcomes (Aslam \& Sadagat, 2011). Procedural justice can be seen as extension of equity theory in perspective of allocation process (Deutsch, 1975). According to Greenberg and Colquitt (2005) procedural justice criteria included the following factors: Voice in making of decisions, consistency in applying rules, accuracy in use of information, opportunity to be heard, and safeguards against bias. Procedural justice has great significance in the organization 
because according to Greenberg and Beron (2008) fairness does not mean that employees are only interested in fair outcomes, but also interested in fair processes used in the determination of their outcomes (i.e., procedural justice).

Procedural justice can be defined as the fairness of the decision-making process in the organization. The existence of procedural justice can be understood by investigating how justice works in the decision-making processes that affect employees' relationships with the organizations and with each other (Korgaard \& Sapienza, 2002). People desire to participate in the decisionmaking processes in organizations and assume control. The justice perceptions of individuals who are involved in the process in organizations are at a higher level (Folger \& Konovsky, 1989).

It is a key concern of every organization to maintain procedural justice as a regular practice because decisions based on unfair practices are not accepted by employees. In fact in case of procedural injustice people do not only consider their outcomes as unfair but also reject the entire system by considering them unfair (Greenberg \& Cropanzano, 2001). People's tendencies to follow company rules were found to be affected by procedural justice practices, therefore top levels officials were advised to promote procedural justice so it would be easy for employees to follow company rules (Greenberg \& Beron, 2008). An instrumental model by Thibaut and Walker's (1975) proposed that procedural justice resulted in more controllable and predictable outcomes so it was highly valued. According to lee (2000), people perceive procedural fairness when process control is given to them in the procedures, and decision control lies with a neutral third party. This study therefore, examines the relationship between procedural justice and organizational citizenship behaviour in Deposit Money Banks in Rivers State. This study was also be guided by the following research questions:

i. To examine the relationship between distributive justice and altruism of Deposit Money Banks in Rivers State.

ii. To examine the relationship between procedural justice and sportsmanship of Deposit Money Banks in Rivers State.

Furthermore, the study shall provide answers to the following research questions:

i. To what extent is the relationship between procedural justice and Altruism of banks in Rivers State?

ii. To what extent is the relationship between procedural justice and Sportsmanship of banks in Rivers State? 
European Journal of Physical Sciences

ISSN 2520-4638 (Online)

Vol.4, Issue 1, pp 40 - 55, 2019

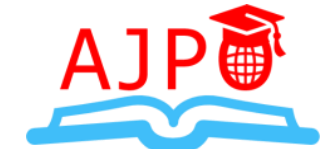

www.ajpojournals.org

\section{LITERATURE REVIEW}

\section{Theoretical Foundation}

The social exchange theory is adopted by this study as theoretically foundation for the assessment of the relationship between workplace justice and organizational citizenship behaviour. Blau (1986) defined social exchange as voluntary actions of individuals that are motivated by the returns they expect from others, as well as values assigned to such relationships. Similar to economic exchange, social exchange generates an expectation of some future return for contributions; however, unlike economic exchange, the exact nature of that return is unspecified. Furthermore, social exchange does not occur on a quid pro quo or calculated basis, but based on individuals' trusting that the other side of the exchanges will fairly fulfil their obligations in the long run (Holmes, 1981). Social exchange theory explains how we feel about a relationship with another person based on our perceptions of: 1) the balance between what we put into the relationship and what we get from it; 2) the kind of relationship we deserve; and 3) the chances of having a better relationship with someone else.

Social exchange theory has been used to explain the various phenomena and processes that occur in organizations, including OCBs (Tsui, Pearce, Porter \& Tripoli, 1997; Tsui\& Wu, 2005). For example, social exchange theory has been used to explain the relationship between employees and the organization (Tsui et al., 1997). Employers utilizing the social exchange approach seek a longterm relationship with employees and show concern about employees' well-being and career development and expect the concern and commitment to be reciprocated.

From the social exchange perspective, if an employee is treated with respect, they would be more likely to engage in OCBs (Cho \& Johanson, 2008). Researchers also found that leaders' and supervisors' support can lead to organizational citizenship behaviour because a social exchange relationship is developed between employees and their supervisors (Organ, 1988; Podsakoff, MacKenzie, Paine \& Bachrach, 2000). Similar findings have also emerged in the context of coworker's social exchange (Ilies, Nahrgang \& Morgeson, 2007; Rhodes \& Eisenberger, 2002).

\section{Procedural Justice}

Procedural justice is defined as the fairness level of the methods, procedures and policies used in determining and measuring factors such as fees, promotions, financial possibilities, working conditions and performance evaluations and administering fairness regarding intra-organization processes, methods and applications and outcomes (Aykut, 2007). While the fairness of the distribution of performance awards is a subject of distributional justice, the fairness of the methods used in determining the same performance awards makes up the subject of procedural justice concept (Ozdevecioglu, 2003). Procedural justice concept first entered the justice literature with the studies of Thibaut \& Walker (1975).

With reference to Guo, (2009) and Wan,Sulaiman \& Omar, (2012), while distributive justice focuses on the resource along with the weights or proportion being given to an employee, procedural justice on other hand evaluate and look at the fairness on the decision-making processes or formal policy adopted to determine the distribution of those resources. This is the core 
distinction between distributive justice and procedural justice. Despite distributive justice had received overwhelming attention from many researchers from the first 20 years after Adam's equity theory is introduced in the 1950s, the focus shifted to procedural justice started mid-1970s to mid-1990s (McNabb 2009). With reference to Guo (2009), the shift of focus happened because researchers had later found that people also concern about how decisions were made decided, on top of what were those decisions about. Thus, the perception and evaluation on justice should have covered more than the outcome itself.

\section{Organizational Citizenship Behaviour}

Studying the duties of the members of an organization that are not included in their job descriptions, in other words, voluntary behaviours, Chester Bernard (cited in Danaeefard, Balutbazeh, \& Kashi, 2010) laid the foundations of the concept of organizational citizenship behaviour. Bateman and Organ (1988) define the organizational citizenship behaviour as good soldier syndrome while George (1991) defines it as pro-social behaviour; George and Brief (1992) define it as a spontaneous behaviour. George and Jones (1997) described the features of organizational citizenship behaviour as comprising organizational voluntarism (or willingness).

Since the main ingredient of social life encompasses human behaviours that require the involvement of many relevant concepts, the definition of OCB varies. Although Organ's (1988) definition is considered to be the first and most renowned, a detailed literature review of Podsakoff, Whitting, Podsakoff and Blume, (2000) revealed the existence of at least 30 different definitions. Consistent with earlier perceptions, Smith, Organ and Near (1983) define the concept of organizational citizenship as discretionary employee behaviour that has no direct or explicit influence on formal reward mechanisms and aims to enhance the level of organizational functioning. Greenberg and Baron (2003) share Smith et al., (1983) ideas and characterize organizational citizenship as an informal individual behaviour that includes an effort larger than the formally expected endeavour in order to enhance organizational productivity and personnel satisfaction.

By focusing on the central functions, Farh, Podsakoff and Organ (1990) emphasize that organizational behaviour requires helping manners among employees as well as being punctual and playing a dynamic role through fulfilling administrative decisions and performing temporary tasks. Similarly, George and Brief (1992) describe citizenship behaviour as an employee's sense of intentional involvement in organizational activities without expecting any type of benefits. In their study on citizenship and marketing services, MacKenzie, Podsakoff and Fetter (1993) state that citizenship behaviour requires discretionary functions in an effort to improve organizational effectiveness without taking individual benefits into account.

\section{Measures of Organizational Citizenship Behaviour}

\section{Altruism}

According to Organ (1990) consists of those voluntary actions that help another person with a work (related) problem. A future-oriented mindset may remind individuals of future potential interactions with their co-workers, which may lead them to be more attentive and helpful toward 
colleagues because they realize that they are likely to see each other again in the future. Second, helping others at the workplace may go along with a future expectation of reciprocal help which may not be returned immediately (Aryee, Budhwar \& Chen, 2002). Thus, as future focus may prompt individuals to hold a long-term perspective on their social relationships at work, it may make them more likely to engage in helping behaviours.

Altruism in simple words means helping or helpfulness (Organ and Ryan, 1995). Altruism means helping other members of the organization in their tasks. For e.g. voluntarily helping new employees, helping co-workers who are overloaded, assisting workers who were absent, guiding employees to accomplish difficult tasks. Smith, Organ, and Near (1983) defined altruism as voluntary behaviours where an employee provides assistance to an individual with a particular problem to complete his or her task under unusual circumstances. Altruism refers to a member helping other members of the organization in their work. Podsakoff et al., (2000) has demonstrated that altruism was significantly related to performance evaluations and correspondingly, positive affectivity.

\section{Sportsmanship}

In comparison to other dimensions presented by Organ (1988), sportsmanship, or tolerating and showing endurance against the consequences of negative working conditions, is given relatively less attention. In exploring the relationship between organizational citizenship behaviours and sales unit effectiveness, Podsakoff and MacKenzie (1994) argue that salespersons show a high level of tolerance even when they experience extensive negative responses and further try to endure misbehaviors without complaints.

Sportsmanship is defined as a willingness to tolerate the inevitable inconveniences and impositions of work without complaining. (Organ,1990). It refers to person's desire not to complain when experiencing the inevitable inconveniences and abuse generated in exercising a professional activity. Sportsmanship refers to avoid complaining unnecessarily about the difficulties faced in the workplace, being positive and tolerant towards problems experienced in the workplace. Sportsmanship is exhibition of willingness to tolerate minor and temporary personnel inconveniences and impositions of work without grievances, complaints, appeals, accusations, or protest. This helps to conserve organizational energies for accomplishment of task and to a large extent relieves managers of unnecessary load/stress (Organ \& Ryan, 1995). Organ (1988) defined sportsmanship as the behaviour of warmly tolerating the irritations that are an unavoidable part of nearly every organizational setting. Podsakoff and MacKenzie (1994) publicized that good sportsmanship would enhance the morale of the employees at the workplace and consequently reduce employee turnover.

This dimension includes having an indulgent manner rather than adopting a complaint manner regarding the problems taking place in the organization. This one helps group members to put in magnificent performance (Organ \& Ryan, 1995). As earlier stated, this dimension, Podsakoff et al., (2000) takes attention to the inefficiency of complaining and the necessity behind putting personal opinions away in bad times of the organization by thinking that and being creative for the 
benefit of the organization. Also, self-sacrifice shown by adopting good manner is the key of the situation.

Bergen and Bandow (2010) assert that promoting tolerance has become a key weapon in battling prejudice and bias within the workplace and this would consequently prompt organization-men to utilise their competencies even outside their stated job roles. The authors further assert that tolerance has changed from the classical definition of incorporating grudging forbearance and indifference toward others and their beliefs and practices to the neo-classical meaning suggesting that every individuals beliefs, values, behaviour, and truth claims are equally valid and worthy of acceptance.

\section{Procedural Justice and Organizational Citizenship Behavior}

Procedural justice is the workers' perception regarding fairness in rules and regulations or procedures which are applied in making decision that will direct the final outcome of the organization (Aryee et al., 2002; Byrne, 2005). Moorman (1991) defined it as "the fairness of the procedures used in determining employee outcomes". Leventhal (1976) stated that normally an individual's evaluations of allocation decisions are affected by both rewards and how rewards are prepared. Konovsky and Pugh (1994) concluded that there is a relationship between procedural justice and organizational citizenship behaviour. Konovsky and Folger (1991) have found a significant relationship between the helping dimension of organizational citizenship behaviour and procedural justice.

Elanain (2010) pointed out that a low level of organizational employees' perceptions of procedural justice and distributive justice will result in increased absenteeism rate, low performance, low loyalty and low citizenship behaviours. When people perceive that they are treated based on fair procedures in determining employee outcome employee may tend to show better performance such as OCB. Because employee may feel they are rewarded fairly based on their actual performance. Therefore, it makes sense that procedural justice has positive relationship with OCB.

From the foregoing argument, the study hypothesized thus:

Ho1:There is no significant relationship between procedural justice and Altruism of Deposit Money Banks in Rivers State.

Ho2:There is no significant relationship between procedural justice and sportsmanship of banks in Rivers State 


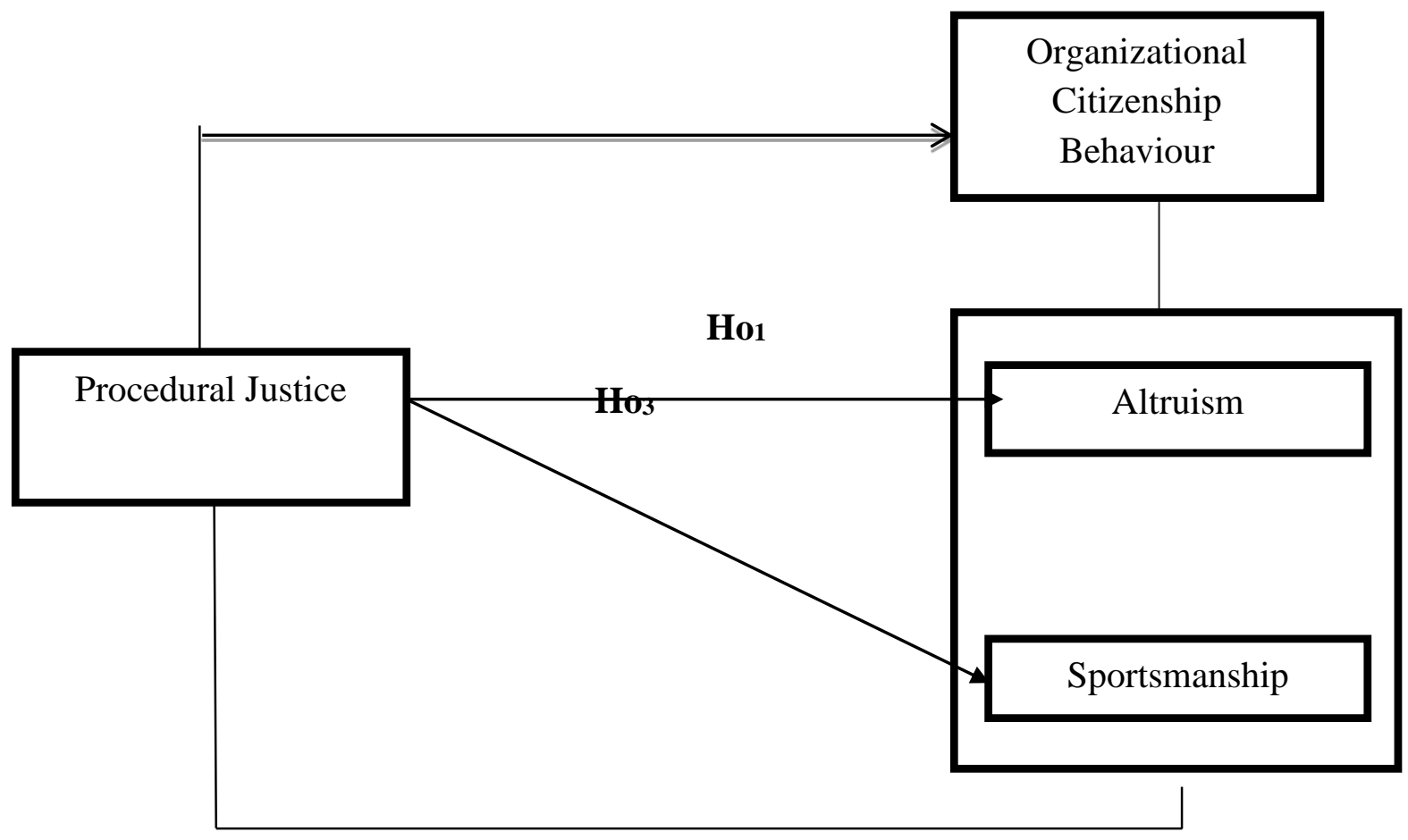

Fig.1 Operational framework for the hypothesized relationship between innovativeness and organizational resilience

Source: Author's Desk Research, 2018

\section{METHODOLOGY}

We adopted a cross sectional survey design. The population of the study was 455 employees of 18 deposit money banks in Rivers State from which the population of 213 was determined using Taro Yamen formula. Data was generated from 193 respondents from the target deposit money Banks in Rivers State. As a quantitative study, the primary data collection instrument for the study was the structured questionnaire. The test for the reliability for the instrument was carried out using the Cronbach alpha reliability instrument with a reliability threshold of 0.70 . The Analysis comprised of the univariate (single variable assessments) bivariate (test for hypothetical relationships) while the bivariate analysis was carried out using the Spearman's rank order correlation coefficient at a 0.05 level of significance. The measurement scale for the variables in this study was based on 5point Likert scale ranging from No extent (NE) to Very high - extent (VHE).

Table 1. Reliability statistics for the instruments

\begin{tabular}{llll}
\hline & $\begin{array}{l}\text { Dimensions/Measures of the study } \\
\text { variable }\end{array}$ & $\begin{array}{l}\text { Number of } \\
\text { items }\end{array}$ & $\begin{array}{l}\text { Cronbach's } \\
\text { Alpha }\end{array}$ \\
\hline 1 & Procedural Justice & 5 & .731 \\
2 & Altruism & 5 & .724 \\
3. & Sportsmanship & 5 & .801 \\
\hline
\end{tabular}

Source: Research data, 2019 


\section{RESULTS AND DISCUSSIONS}

\section{Bivariate Analysis}

Data analysis was carried out using the Spearman rank order correlation tool at a $95 \%$ confidence interval. Specifically, the tests cover the hypotheses that were bivariate and declared in the null form. We have based on the statistic of Spearman Rank (rho) to carry out the analysis.

Decision rule: The decision rule which applies for all bivariate test outcomes is stated as follows: where $\mathrm{P}<0.05$, reject hypothesis on the basis or evidence significant relationship; and where $\mathrm{P}>$ 0.05 , accept hypothesis on the basis of insignificant relationship between the variables. The extent of influence is on this basis assessed using the rho interpretations provided by Bryman and Bell (2003), where:

Rho $=00-.19$ "very weak"

Rho $=.20-.39$ "weak"

Rho $=.40-.59$ "moderate"

Rho $=.60-.79$ "strong"

Rho $=.80-1.0$ "very strong"

We will begin by presenting first a test of existing relationships.

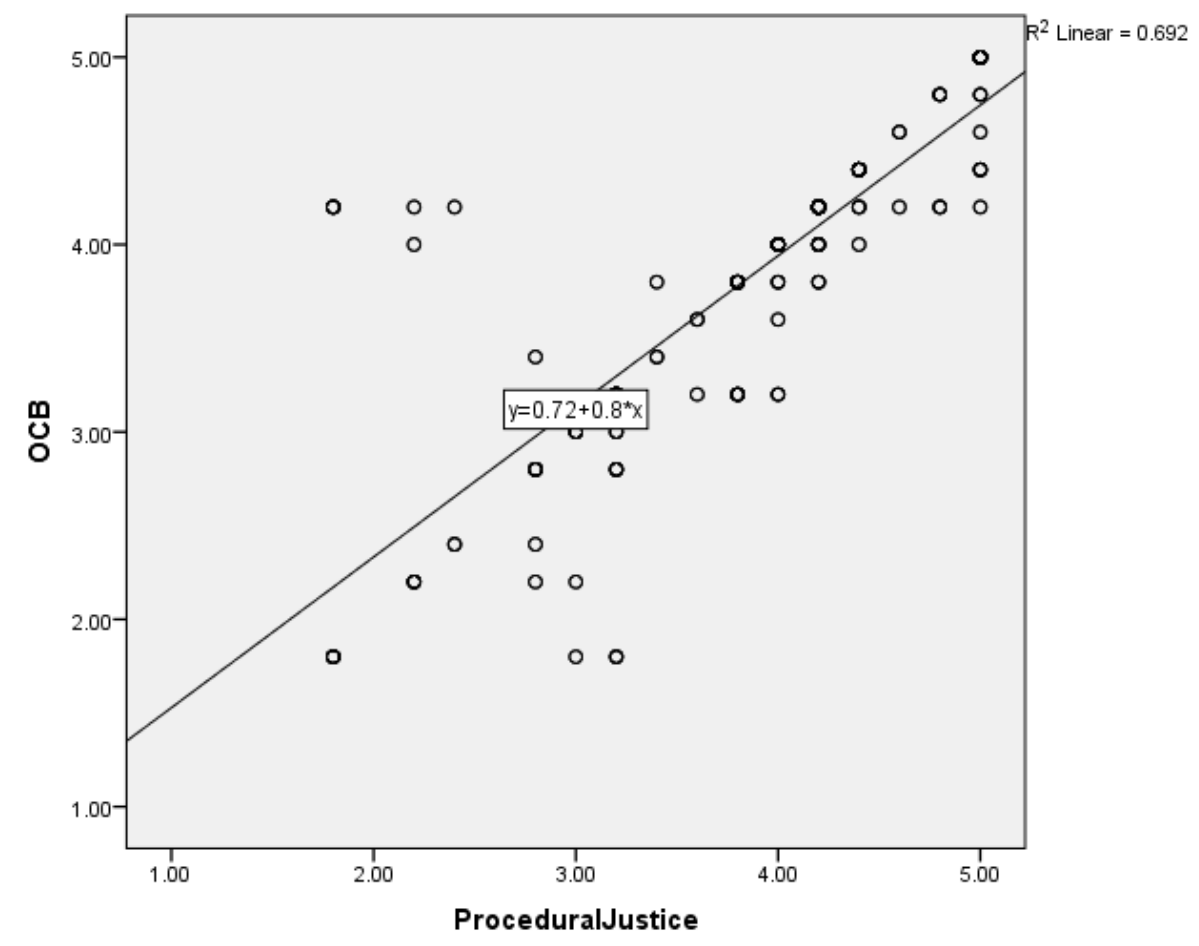


European Journal of Physical Sciences

ISSN 2520-4638 (Online)

Vol.4, Issue 1, pp 40 - 55, 2019

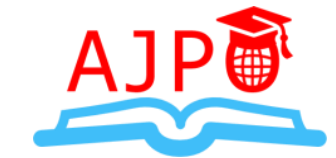

www.ajpojournals.org

Figure 2 scatter plot relationship between procedural justice and organizational citizenship behaviour

The scatter plot graph shows at $\mathrm{R}^{2}$ linear value of (0.692) depicting a strong relationship between the two constructs. The implication is that an increase in procedural justice simultaneously brings about an increase in the level of organizational citizenship behaviour. The scatter diagram has provided vivid evaluation of the closeness of the relationship among the pairs of variables through the nature of their concentration.

\begin{tabular}{lllccc}
\hline & & $\begin{array}{c}\text { Procedural } \\
\text { Justice }\end{array}$ & Altruism & Sportsmanship \\
\hline Spearman's rho & Procedural & Correlation & 1.000 & $.579^{* *}$ & $.588^{* *}$ \\
& Justice & Coefficient & & .000 & .000 \\
& & Sig. (2-tailed) &. & 193 & 193 \\
& N & Correlation & $.579^{* *}$ & 1.000 & $.959^{* *}$ \\
& & Coefficient & .000 &. & .000 \\
& Sig. (2-tailed) & 193 & 193 & 193 \\
& Sportsmanship & Correlation & $.588^{* *}$ & $.959^{* *}$ & 1.000 \\
& Coefficient & .000 & .000 &. \\
& Sig. (2-tailed) & 193 & 193 & 193 \\
\hline
\end{tabular}

\section{Hol: There is no significant relationship between procedural justice and altruism of banks in Rivers State}

From the result in the table above, the correlation coefficient shows that there is a positive relationship between procedural justice and altruism. The correlation coefficient 0.579 confirms the magnitude and strength of this relationship and it is statistically significant at p $0.000<0.05$. The correlation coefficient represents a high correlation between the variables. Therefore, based on empirical findings the null hypothesis earlier stated is hereby rejected and the alternate accepted. Thus, there is a significant relationship between procedural justice and altruism of banks in Rivers State

\section{Ho2: There is no significant relationship between procedural justice and sportsmanship of banks in Rivers State}

From the result in the table above, the correlation coefficient shows that there is a positive relationship between procedural justice and sportsmanship. The correlation coefficient 0.588 confirms the magnitude and strength of this relationship and it is statistically significant at $\mathrm{p}$ $0.000<0.05$. The correlation coefficient represents a high correlation between the variables. Therefore, based on empirical findings the null hypothesis earlier stated is hereby rejected and the 
European Journal of Physical Sciences

ISSN 2520-4638 (Online)

Vol.4, Issue 1, pp 40 - 55, 2019

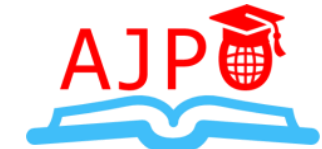

www.ajpojournals.org

alternate accepted. Thus, there is a significant relationship between procedural justice and sportsmanship of banks in Rivers State

\section{DISCUSSION OF FINDINGS}

The results show that there is a significant relationship between procedural justice and the measures of organizational citizenship behaviour. In this vein, all related null hypothetical statements are rejected. Research has also demonstrated that employees' status and position within an organization can influence reactions to events. Aquino, Tripp, and Bies (2006) conducted a field study and experimental study of victimization in an organization, examining three organizational factors relating to victim response (revenge, forgiveness, reconciliation).

The three organizational factors examined were (a) relative hierarchical status of the victim, the position of the victim relative to the aggressor's position in the organization (e.g., employee-coworker vs. employee-supervisor); (b) absolute hierarchical status of the victim, the victim's position in the organization (patrol officer or supervisor); and (c) procedural justice climate, which refers to the manner in which the organization promotes fair outcomes and redresses acts of injustice. They found that when victims have a lower status than the offender and when the procedural justice climate is low, the victims will pursue revenge. Furthermore, these research studies showed that procedural justice climates were related to forgiveness and reconciliation.

Simply, when an employee is a victim and cannot rely on the organization to punish the offender, the victim will administer his/her own personal justice. From this research, if officers feel that the department will not address the perceived mistreatment by a supervisor, then they will respond in vengeful behaviours. Conversely, when an employee has faith that the organization will sanction the wrongdoer (procedural justice climate), the employee is more likely to reconcile or forgive.

This is important because patrol officers make up the majority of citizen-police encounters, but often hold the lowest absolute hierarchal status and relative hierarchal status within the department. Thus, they would most likely be the ones who would engage in counterproductive behaviours such as revenge. Aquino et al., (2006) remarked. Our findings suggest that how people respond to such experiences is not just a function of individual factors or traits; rather, environmental variables such as power and procedural justice climate are critical in shaping individual responses.

Whitener (1997) found that employees trust in their supervisor forms their perceptions of the success, accuracy and fairness of HR system used by the organization. Folger and Konovsky (1989) reinforced this view when they found that the process used by supervisors to make decisions would have a greater impact on fairness perceptions of employees than the pay raise outcomes themselves. Erdogan (2002) studied justice perceptions in the use of performance appraisals as performance appraisal is an important HR practice having implications for important individual decisions (pay raises and promotions).

Supervisors have been viewed in various studies as key persons in forming justice perceptions about performance appraisals as they are the main evaluators of individual's performance. Erdogan (2002) termed them as most influential raters. It has also been suggested by Ergodan (2002) that individuals assume that members having high quality LMX will have positive outcomes such as 
career progress and salary progress During the performance appraisal process, it is the supervisor who communicates with the member as a result of which individuals procedural justice perceptions are shaped. It might be noted that some of the researchers differentiated procedural and interactional justice by assuming that supervisor's behaviours can affect only interactional justice and not procedural justice Erdogan (2002) contributed to the literature on justice perceptions regarding performance appraisals by dividing procedural justice in to two sub dimensions.

Prior empirical research has provided considerable evidence that the level of organizational justice is directly related to the quality of social exchange relationships between individuals and their employing organizations and has proven to be a significant predictor of a number of important employee attitudes and behaviours including job satisfaction, organizational commitment, organizational citizenship behaviour and intentions to leave (Masterson et al., 2000; Rupp \& Cropanzano, 2002).

Malatasta and Byrne (1997) tested the proposition that procedural and interactional justice differ because they are associated with different distinct outcomes of social exchange relationships. According to their model, perceptions of procedural justice are based on an organization's formal policies. They found that individuals reciprocate perceptions of fairness in procedures by exhibiting organizational commitment and organizational citizenship behaviour. Furthermore, they suggested different outcomes of interactional justice thus making a distinction between procedural and interactional justice. They showed in their findings that interactional justice perceptions of individuals lead them to reciprocation in form of commitment and organizational citizenship behaviour directed towards supervisor.

Masterson et al., (2000) arrived at similar conclusion. They suggested in their studies that procedural justice involves social exchange with the employing organization. Perceptions of procedural justice give employees feelings of POS which gives higher sense of organizational commitment and fewer intentions to quit. Malatasta et al., (1997) moreover, concluded that interactional justice on the other hand, causes high quality leader-member exchange which in turn results in organizational citizenship behaviour related to supervisor and higher job satisfaction. They tested their model with two studies both of which supported their hypothesis and theoretical explanations. As was found for LMX, distributive justice was a consistent predictor of commitment as well. This demonstrates that organizations that provide equitable and fair rewards for their employees can increase the level of commitment shown by their employees.

\section{CONCLUSION AND RECOMMENDATION}

Procedural justice is the perceived fairness of the procedures to get the outcome. This study concludes therefore that procedural justice significantly influences organizational citizenship behavior of Deposit Money Banks in Rivers State. The study recommends that Bank managers should first improve the procedural justice and hence increase overall levels of perceived justice by involving employees in the procedures used in making decisions and allocating rewards. Procedural justice can be fostered further through employee involvement which gives them a voice during a decision-making process, influence over the outcome or by adherence to fair process criteria, such as consistency, lack of bias, correctability, representation, accuracy, and ethicality. 
The results of this study provide both theoretical and practical implications. First, this study represents the theoretical or empirical research regarding the consequences of workplace justice in the banking industry. Despite the fact that workplace justice is an important factor as a basic requirement for the effective functioning of organizations (Greengberg, 1994), there have been few empirical researches of workplace justice in the banking industry.

Therefore, the perception of, how employees judge about fairness in their organization, and how they respond to understanding of justice or injustice, is one of the important matters for administrators and managers of banks that there should be more effort to increase perceptions of employees about workplace justice by making transparent rules, procedures and organizational policies which are related to job and it explains procedures of resource allocation and rewards of organization. Then, based on program goals and mission of the organization, making comprehensive program to improve and develop job attitudes, feeling of opting for voluntary services spontaneously, finally brings the efficiency as well as efficacy to the activities of the organization.

\section{REFERENCES}

Aslam R. \& Sadaqat S (2011). Investigating the relationship of organizational justice on organizational citizenship behavior among teaching staff of university of the Punjab. European Journal of Scientific Research, 57(1), 53-67.

Aykut, S. (2007). Örgütsel Adalet, Birey-Örgüt Uyumu ile Çalışanların İşle İlgili Tutumları: Pendik İlçesi Örneği. (Yayınlanmamış Yüksek Lisans Tezi), Yeditepe Üniversitesi Sosyal Bilimler Enstitüsü.

Aryee, S., Budhwar, S. P. \& Chen, X. Z. (2002). Trust as a mediator of the relationship between organizational justice and work outcomes: Test of a social exchange model. Journal of Organizational Behavior. 23, 267-285. Wiley Interscience. Retrieved on June 26, 2012 from http://www.jstor.org/stable/4093804

Azmi, F. T., Desai, K., \& Jayakrishnan, K. (2016). Organization citizenship behaviour (OCB): A comprehensive literature review. Sumedha Journal of Management, 5(1), 102.

Bateman, T.S. \& Organ, D. W. (1983). Job satisfaction and the good soldier: The Relationship Between Affect And Employee Citizenship. Academy of Management Journal, 26, 587-595

Borman, W. C., \& Motowidlo, S. J. (2014). Organizational citizenship behaviour and contextual performance: A special issue of human performance. United States of America: Taylor \& Francis.

Blau, P.M. (1986). Exchange and power in social life. New Brunswick, New Jessy: Wiley \& Sons, Inc. 
Cho, S., \& Johanson, M. (2008). Organizational citizenship behavior and employee performance: moderating effect of work status in restaurant employees. Journal of Hospitality and Tourism Research, 32, 307.

Day, A. L., \& Carroll, S. A. (2004). Using an ability-based measure of emotional intelligence to predict individual performance, group performance, and group citizenship behaviours. Personality and Individual Differences, 36, 1443-1458.

Danaeefard H., Balutbazeh A.E. \& Kashi K.H.A (2010). Good soldiers' perceptions of organizational politics understanding the relation between organizational citizenship behaviors and perceptions of organizational politics: Evidence from Iran, European Journal of Economics, Finance and Administrative Sciences, 18, 146-162

Deutsch, M. (1975). Equity, equality, and need: What determines which value will be used as the basis of distributive justice? Journal of Social Issues, 31, 137-150.

Erdogan, B. (2002). Antecedents and consequences of justice perceptions in performance appraisals. Human Resource Management Review, 12, 555-578.

Farh, J. L., Zhong, C. B., \& Organ, D. W. (2004). Organizational citizenship behavior in the People's Republic of China. Organization Science, 15, 241-253.

Farh, J. L., Podsakoff, P. M., \& Organ, D. W. 1990. Accounting for organizational citizenship behavior: Leader fairness and task scope versus satisfaction. Journal of Management, 16: $705-721$

Folger, R., \& Konovsky, M. (1989). Effects of procedural and distributive justice on reactions to pay raise decisions. Academy of Management Journal, 32: 115-130.

George J.M. \& Jones, G.R. (1997). Organizational spontaneity in context, Human Performance, $10(2), 153-170$.

George, J.M. (1991). State or trait: Effects of positive mood on prosocial behaviors at work ", Journal of Applied Psychology, 76(2), 299-307.

Greenberg, J. \& Baron, R. (2008).Behaviors in organization, Dorling Kindersley ( India) Pvt. Ltd.

Greenberg, J., \&Colquitt, J. A. (Eds.). (2005). Handbook of organizational justice. Mahwah, NJ, US: Lawrence Erlbaum Associates Publishers.

Greenberg, J., \& Cropanzano, R. (2001). Advances in organizational justice. Stanford, CA: Stanford University Press.Ng, S. M., Ke, G. N., \& Raymond, W. (2014). The mediating role of work locus of control on the relationship among emotional intelligence, organisational citizenship behaviours, and mental health among nurses. Australian Journal of Psychology, 66(4), 207-215. 
Guo, C. (2009). The meaning and effects of organizational justice in a layoff situation: An indigenous chinese investigation. (Order No. 3379961, University of Massachusetts Amherst). ProQuest Dissertations and Theses, 196. Retrieved from http://search.proquest.com/docview/304924039?accountid=50207. (304924039).

Holmes, J. G. (1981). The exchange process in close relationships: micro-behaviour and macromotives, in Lerner, J.M., Lerner, C.S. (Eds). The justice motive in social behaviour, New York, NY: Plenum.

Ilies, R., Nahrgang, J. D., \& Morgeson, F. P. (2007). Leader-member exchange and citizenship behaviours: A meta-analysis. Journal of Applied Psychology, 92, 269-277.

Katz, D. (1964). The motivational basis of organisational behaviour. Behavioural Science 9: 13146.

Korgaard M., \& Sapienza, H. (2002). Toward an integration of agency and procedural justice theories. In S. Gilliland, D. Steiner D. Skarlicki (Eds.), emerging perspectives on managing organizational (3-34). Charlotte, NC: Information Age Publishing.

Lee, H. (2000). An empirical study of organizational justice as a mediator of the relationships among leader-member exchange and job satisfaction, organizational commitment and turnover intentions in the lodging industry. An unpublished doctoral dissertation. Virginia Polytechnic Institute and State University.

McNabb, N. S. (2009). The daily floggings will continue until morale improves: An examination of the relationships among organizational justice, job satisfaction, organizational commitment and intention to turnover (Order No. 3352987). Available from ProQuest Dissertations \& Theses Global. (304972141). Retrieved from http://search.proquest.com/docview/304972141 accountid=50207

Masterson, S.S. Lewis, K., Goldman, B.M., \& Taylor M.S. (2000). Integrating justice and social exchange: The differing effects of fair procedures and treatment on work relationships. Academy of Management Journal. 43, 738-748.

Malatesta, R. M., \& Byrne, Z. S. (1997). The impact of formal and interactional procedures on organizational outcomes. Paper presented at the 12th annual conference of the Society for Industrial and Organizational Psychology, St. Louis, MO.

Organ, D.W. \& Ryan, K. (1995). A meta-analytic review of attitudinal and dispositional predictors of organizational citizenship behaviour, Personal Psychology, 48(4), 775-802.

Organ, D. W. (1990). The motivational basis of organizational citizenship behavior. In Staw, B. W. Staw\& L. L. Cummings (Eds.), Research in Organizational Behavior, 12 (pp. 43-72), JAI Press, Greenwich, CT.

Organ, D. W. (1988). Organizational citizenship behavior: The good solider syndrome. Lexington, MA: Lexington Books 
Özdevecioğlu, M. (2003). Algılanan Örgütsel Adaletin Bireylerarası Saldırgan Davranışlar Üzerindeki Etkilerinin Belirlenmesine Yönelik Bir Araştırma. Erciyes Üniversitesi İktisadi ve İdari Bilimler Fakültesi Dergisi, Sayı 21: 77-96.

Podsakoff, N. P., Podsakoff, P. M., Mackenzie, S. B., Maynes, T., \& Spoelma, T. (2014). Consequences of unit-level organizational citizenship behaviors: A review and recommendations for future research. Journal of Organizational Behavior, 35(51), S87S119

Podsakoff, N. P., Whitting, S. W., Podsakoff, P. M., \& Blume, B. D. (2009). Individual and organizational level consequences of organizational citizenship behaviour: A meta-analysis, Journal of Applied Psychology, 94(1), 122-141.

Podsakoff, P. M., MacKenzie, S. B., Paine, J. B., \& Bachrach, D. G. (2000). Organizational citizenship behaviours: A critical review of the theoretical and empirical literature and suggestions for future research. Journal of Management, 26, 513-563.

Podsakoff, P. \& MacKenzie, S.B. (1994). Organizational citizenship behavior and sales unit effectiveness. Journal of Marketing Research, 31, 351-363.

Rhodes, L., \& Eisenberger, R. (2002). Perceived organizational support: A review of the literature. Journal of Applied Psychology, 87, 698-714.

Rupp, D.E., \& Cropanzano, R. (2002). The mediating effects of social exchange relationships in predicting work place outcomes from multifoci organizational justice. Organizational behavior and human decision process. 89, 925-946.

Smith, C. A., Organ, D. W. \& Near, J. P. (1983). Organisational citizenship behaviour: Its nature and antecedents. Journal Applied Psychology, 68, 653-63

Thibaut, J., \& Walker, L. (1975). Procedural justice: A psychological analysis. Hillsdale, NJ: Erlbaum

Tsui, A. S., \& Wu, J. B. (2005). The employment relationship versus the mutual investment approach: Implications for human resource management. Human Resource Management, 44(2), 115-121.

Tsui, A. S., Pearce, J. L., Porter, L. W., \& Tripoli, A. M. (1997). Alternative approaches to the employee-organization relationship: Does investment in employees pay off? Academy of Management Journal, 40(5), 1089-1121.

Wan, H., Sulaiman, M., \& Omar, A. (2012). Procedural Justice in Promotion Decisions of Managerial Staff in Malaysia. Asia Pacific Business Review, 18(1), 99-121. doi:10.1080/13602380903424167 